especially the will. Whatever tends to obliterate suffering conserves the strength of all the faculties of both mind and body, and thus lessens the liability of relapse after the patient leaves the sanatorium.

A few minutes after reading Dr. Jennings's criticism I chanced to meet a nurse who cared for her sister while she was under my treatment for morphinism. I told her of this criticism, and she reminded me of her own experience. Her sister had taken treatment for morphinism in two institutions before coming to me. In both places they used the usual painful reduction method, without much reliance upon drugs, and after each treatment she promptly relapsed. Since taking treatment with me she has not returned to the use of morphine, and long since resumed her usual work, maintaining the best of health. One of the glories of modern medicine is its conquest of pain. It is no mean achievement to keep a patient free from suffering while nature or art is busy restoring him to health. This is the object of my treatment of morphinism.

I am, Sir, yours faithfully,

Dorchester, Mass., U.S.A., Nov. 5th, $1909 . \quad$ C. J. Dougl.AS.

\section{HOSPITALS AND THE LONDON COUNTY COUNCIL: MEDICAL TREATMENT OF SCHOOL CHILDREN.}

To the Editor of THE LA CET.

SIR,- There seems to be as great a diversity of interpretation of the arrangements entered into between various hospitals and the London County Council regarding the special medical treatment of children attending the Council schools, as there is difference of opinion in the prudence of such arrangements.

In the hope that the position taken up by the committee of the Central London Throat and Ear Hospital will commend itself to their subscribers, to the charitable public, and to the medical profession, I venture to give the resolution passed at our recent meeting, viz. :-

That the committee of the Central London Throat and Ear Hospital is willing as hitherto, to receive those chilaren of the Londun County Council schools who are suitable for hospital treatment so far as the capacity and resources of the hospital will allow.

It will be seen that we neither enter into financial contract nor give preferential treatment, our intention being to receive the children on their merits, not because they are children under the supervision of the L.C.C. but because they are children of the poor who have a claim on our sympathy and our assistance, the only passport needed being illness and the absence of means to pay for the adequate medical treatment of that illness.

I am, Sir, yours faithfully,

Central London Throat and Ear Hospital,

Grays Inn-road, Nov. 17th, 1909.

\section{THE EYESIGHT OF SCHOOL CHILDREN.}

\section{Io the Editor of THE LANCET.}

SIR,-May I suggest that the medical officers who are examining school children in the elementary schools should inquire what kind of artificial illumination is provided in the school by which the children have to perform their writing and reading lessons during the dark foggy days so prevalent at this season of the year? I understand that in some schools there is quite inadequate illumination, the ordinary old-fashioned gas-jet being used without applying the modern methods of illumination, even by those boroughs which have electricity works of their own. Examination of the children's eyes at this time of the year could conceivably show the effects of eyestrain due to this cause and give misleading results for tabulating purposes.

I am, Sir, yours faithfully,

London, Nov. 17th, 1909.

A PARENT.

Literary Intelligence.-Messrs. Baillière, Tindall, and Cox will shortly publish a handbook by C.tptain E. Blake Knnx, R.A.M.C., M.D., D.P.H., entitled "Aids to" Microscopic Diagnosis (Bacterial and Parasitic Disease)," which will present a concise account of clinical laboratory technique.

\section{BIRMINGHAM.}

(From OUR OWN CotrRgsPoNDHNT.)

\section{Institute of Sanitary Engineer's.}

Mr. J. D. Watson, engineer to the Birmingham Drainage Board, delivered his presidential address to the Birmingham and Midland section on Nov. 16th. The subject was "The Disposal of Sewage at a Country House." He directed attention to the need of making owners and occupiers realise the need for improvement and for efficient methods of dealing with sewage. Many beautiful streams were polluted because no attempt at purification of sewage was made. A natural method of purification was the best, and that might be done by land irrigation or by artificial means or bacteria beds according to circumstances. The quality and suitability of land were of great importance, some soils being capable of purifying more than 30,000 gallons of sewage per acre per day, and other soils not a tenth of that amount. Assuming a typical country house inhabited by ten people, with a total volume of sewage of about 300 gallons per day, he recommended the establishment of a bacterial plant on the percolation system.

\section{Parents' National Educational Union.}

The annual conference was held in Birmingham from Nov. 15th to 19th. Much interest has been taken in its proceedings. On the first day a large meeting, presided over by Lord Lytton, was held in the great ball of the new University buildings, and an address was given by Sir Oliver Lodge. Among other notable addresses were those by the Bishop of Birmingham on "Shall we send our Sons to the University?"; by Canon J. H. B. Masterman on "The Education of the Imagination"; by Sir Martin Conway on "How to Interest Young People in Art" ; and by Dr. Helen Webb on "Environment in Relation to Nervous Stability."

\section{Deatí of Alderman Alfred Barratt, M.R.C.S. Eng., L.R.C.P. Edin.}

$I$ record with regret the death of Alderman Barratt on Nov. 18th at the age of 81 years. Mr. Barratt was trained at Queen's College, Birmingham, and qualified in 1855. For about 30 years be worked a large general practice in a thickly populated artisan district. In 1870 he was elected to the town council and joined the small band of publicspirited men who, under the leadership of $\mathrm{Mr}$. Joseph Chamberlain and Mr. Jesse Collings, strove successfully to reform the constitution of the council and its methods of working, so bu inging about a vast improvement in the town. His professional knowledge was of great service to the health committee, drainage board, and estates committee, of which he was a member. He was also a member of the committee which carried out the great improvement scheme when a number of old slums were cleared away to make room for handsome business streets. For 20 years be was a member of the board of guardians, of which he was chairman in 1885. At the time of his death he was a member of the board of overseers. He lived a strenuous life, and was a good example of a public man actuated by the highest motives.

\section{Royal Leamington Spa.}

The town council has decided to enter upon a scheme to reorganise the baths and make them better known. A weak saline water is to be supplied in addition to the strong saline water now in use; a medical pamphlet will be drawn up; a sum not exceeding $\$ 500$ will be spent on advertising; and an annexe to the pump room will be provided.

\section{Nuneaton General Hospital.}

At the annual meeting of the supporters of this hospital a motion was proposed to rescind the rule restricting the hospital medical staff to six, and substituting a rule that all the duly qualified medical men in the town after 12 months' residence should be members of the staff, if they desired, on application to the nianagement committee. It was pointed out that working men contended that patients when they go into hospital should have the privilege of being attended by their own medical men. After a long discussion the motion was lost hy 60 votes to 48 .

Nov. 23rd. 